Matgorzata Zaleska

The Institute of Banking, Warsaw School of Economics

\title{
ACTORS OF THE INSTITUTIONAL REFORMS OF THE EUROPEAN BANKING SECTOR IN RESPONSE TO THE CRISIS
}

\begin{abstract}
The article presents the main European policy makers implementing the reform of the banking sector in response to the contemporary global financial crisis. The institutional changes are assessed in the paper, including the establishment of the European banking union, modifications in the EU deposit insurance systems and considerable strengthening of the role of central banks, with special focus on the European Central Bank. Moreover, potential sources of another financial crisis are identified and further institutional changes in finance are proposed.
\end{abstract}

Key words financial crisis, banking reforms, financial safety net, central bank

\section{Introduction}

For years, in response to financial crises, new regulations have been created in the financial sector and the old ones have been changed. On the pretext of increasing financial safety and protecting clients of financial institutions, the number of regulations and their complexity is increased. The same occurred in response to the last contemporary global financial crisis of our times.

The foregoing raises the question about the optimum scale of financial markets and their regulation, and also about the balance point between the market mechanisms and the degree of state interventionism. The answer is not simple and our analysis of the status quo leads to the conclusion that regulations are becoming more and more complicated and they can be understood perhaps only by their authors. Moreover, the structure of compliance divisions, which are always more popular in financial institutions, is becoming excessively elaborate.

Institutional changes are introduced by policy makers, i.e. the main actors of the transformations. Nonetheless, they affect numerous business entities and the general public. The most important, although not the only actors of the changing European banking landscape are: the Eurogroup, European Commission, European Parliament and Council as well as Member State governments and institutions of the European financial safety net, in particular the European Central Bank, and Systemically Important Financial Institutions (SIFIs). The new actors, created in reaction to the contemporary global financial crisis, include new bodies of macro- and microprudential supervision and new organs which emerged within the European banking union. The actors of the transformations are therefore many, perhaps even too many.

The article will discuss the institutional changes referred to the financial sector, which in the author's opinion are most significant, with special focus on the banking sector - proposed in reaction to the last contemporary global financial crisis. Our attention will also concentrate on the European reforms and on the main policy makers 
mentioned above. This will let us present the role of the policy makers and analyse the changes which they introduced in the European financial system.

\section{Financial crises}

The concept of financial crisis is differently defined in theory and in practice. Most often, it is associated with panic on the markets (bank runs) or with a significant loss of asset value. Along with the concept of financial crisis, we speak of currency and debt crises. The contemporary crisis has shown that a clear-cut distinction between the types of crises mentioned above is not justified since financial problems of large banks and bail-out operations to prevent their failure led to considerable worsening of the condition of public finance in some countries.

Analysis of the contemporary global financial crisis has shown that it developed in two phases. The first phase of the crisis was largely manifested by:

- bankruptcy of a series of financial institutions,

- limited access to liquidity,

- greater risk aversion.

The second stage of the crisis had the following symptoms:

- worsening of the condition of public finances (especially in PIIGS countries),

- greater borrowing demand of the countries,

- sudden increase in public debt to GDP ratio,

- higher profitability of government bonds,

- lowering of some countries' rating.

Crises on the financial markets have always occurred and always will. Usually, they are generated by a combination of several factors. It is quite challenging to predict when the next crisis is going to arise, what will be its reasons, scale and outcome. Therefore, safety net institutions devise and apply early warning systems, which are supposed to identify both systemic threats and those affecting individual banks.

It should be remembered that threats to the sector and to individual banks may not be directly connected with their banking activity but they may come from outside. Crisis situations may be triggered by terrorist attacks, failures of communications networks and IT systems as well as power cuts. Policy makers should definitely turn their attention to the threats connected with cyber security since this kind of risk seems to have been underestimated. This will also pose a challenge of ensuring public expense necessary to raise the security level and to finance welfare programmes which are being increasingly developed.

Because of the importance of the financial system in the entire institutional order of the country, a framework for crisis management is created with reference to the banking sector. The crisis management framework should include a set of rules and legislation concerning recovery proceedings and bank failure. Moreover, they should also refer to threat identification (early warning systems mentioned above), development of emergency plans and drawing conclusions from crisis situations for the future (,lessons from the crisis”). Unfortunately, our observations so far have shown that conclusions drawn from crises are relatively quickly forgotten by the policy makers and by the general public.

It has been confirmed that fundamental errors in bank (including credit) risk management, greed of the bankers and indolence of the regulators led to the 
contemporary global financial crisis. One could even say that all the actors contributed to the contemporary global financial crisis.

In crisis situation, central banks (also as lenders of last resort) have a special role to play, similarly to the bodies which may carry out resolution or pay out guaranteed deposits should the savings be unavailable in the bank. Both these entities may also support banks experiencing financial difficulty. Crisis management referred to individual banks essentially consists in taking a decision whether to save a bank or declare its bankruptcy. We should also remember about the „too big to fail” rule, which means that the largest banks will in principle be saved if they fall into financial trouble. In the case of a systemic crisis, the main challenges are to restore trust, reduce uncertainty and support liquidity on the bank market, including the interbank market, where banks lend funds to each other.

\section{European Union, Eurozone - diagnosis and directions of change}

First, it has to be said that policy makers have not succeeded yet in creating an optimum currency area within the European Union and the original assumptions of the Eurozone have not been met (the Eurozone still is not an optimum currency area). Among others, high level of wage flexibility and labour mobility, high degree of capital mobility and of intra-industry trade development have not been achieved. Moreover, it is difficult to implement the same monetary and economic policies in the countries of so different economic situation as it is the case in the Eurozone. Thus, conflicting national interests are more and more often revealed within the Community, i.e. the Eurozone. Reforming the Eurozone without removing the original flaws is therefore difficult and will probably not produce the desired outcome.

Taking a broader look at the European Union, it should be noted that the long-term competitive advantage of Europe over the world has not been gained nor has permanent economic growth without significant interference been achieved. Additionally, the idea of cooperation and solidarity of Member States appeared to be a void concept as the interests of France and Germany have dominated so far.

In response to the contemporary global financial crisis, the Eurozone policy makers, including the Eurogroup with the leading role of Germany and France, were confronted with a dilemma whether the Eurozone should disband or further integrate. They chose the second option, which was outlined in the document entitled „Towards a Genuine Economic and Monetary Union", published in 2012. Within the target Economic and Monetary Union four pillars have been identified:

- integrated financial framework,

- integrated budget framework,

- integrated economic policy framework,

- legitimacy and democratic responsibility.

It has to be noted that the main Eurozone problem so far was not a lack of framework, criteria, gauges and indexes, but a lack of compliance therewith and its widespread tacit approval. Policy makers created the rules and then „turned a blind eye” to the fact that they were not observed.

On the other hand, national governments of Member States tried to:

- boost domestic demand and stop the increase of unemployment rate, 
- introduce budget savings policies,

- seek new income sources,

- pursue an active fiscal policy.

One should not forget about the national public aid. From October 2008 till October 2012 the European Commission approved funding for the financial sector totalling 5.06 billion Euro (40.3\% of EU GDP). The aid was addressed in principle to all the UE Member States except for Bulgaria, Czech Republic, Estonia, Malta and Romania.

\section{European banking reforms - selected aspects}

\section{European banking union}

Under the integrated financial framework a European banking union was envisaged to include three pillars:

- Single Supervisory Mechanism,

- Single Resolution Mechanism,

- European Deposit Insurance Scheme.

The first two pillars have been implemented while the third one, i.e. the European Deposit Insurance Scheme is still being discussed (it is due to be fully implemented only in 2024). The project of the European banking union is still unfinished, and therefore incomplete.

The main role in carrying out the European banking supervision is played by the European Central Bank, which will be discussed below (in the section devoted to the change in the role of the European Central Bank).

The idea of resolution consists in structured liquidation of the banks which found themselves in considerable financial difficulty. There should be first and foremost the bank shareholders and creditors and not tax payers and bank clients (in extremis those who have deposits exceeding 100 thousand Euro) to pay for these problems. Although the above concept is interesting, we should bear in mind enormous difficulties in its implementation when it comes to major European banks. Special European resolution fund will total several tens of billions Euro (finally it should be approx. 55 billion Euro), while the asset value of the largest European banks is expressed in billions of Euro. It will not be possible to apply the resolution procedure successfully to the largest European banks.

The Single Resolution Board is a body supposed to take the decision to adopt the resolution mechanism and to implement the process of its supervision. However, since the Single Resolution Board is not envisaged in the Treaty on the functioning of the European Union, in order to avoid possible complaints, it was decided that final decisions with regard to resolution will be made by the European Commission and the European Council. This means that the institution will „multiply”, the boundaries of its competences and responsibilities will be blurred, decision-making will take more time and the risk of premature disclosure of information to the public will grow, which may potentially trigger a run on banks. The Single Resolution Board is also supposed to manage the European Deposit Insurance Scheme in the future. The fact that there will be no new entity established within the European banking union is definitely positive. Moreover, it should be noted that in the case of serious problems of a bank, it will be possible to carry out a resolution process or declare bankruptcy of the bank and pay out 
the guaranteed deposits. Decisions in this area should be taken by a single institution rather than a few different bodies.

The European banking union is also obligatory for the Eurozone countries, while Member States outside the Eurozone may but do not have to join the union on the so called close cooperation basis. However, so far not a single state has established such close cooperation since there seem to be no real advantage thereof. Close cooperation does not necessarily mean e.g. access to funding and liquidity instruments offered by the European Central Bank, which in turn means different position of different states within a single banking union project.

\section{Deposit Insurance Scheme in EU Member States}

Deposit insurance schemes on the financial market may adopt a form of integrated or differentiated (specialized) model. In the integrated model, a single institution guarantees reimbursement of the funds collected on the financial market. In the differentiated model, the funds collected within a segment of the financial market are guaranteed by different institutions. In Poland for example, deposits held in banks and credit unions are guaranteed by the Bank Guarantee Fund, while funds deposited in instruments held on investment accounts e.g. in brokerage houses - by the National Depository for Securities. Meanwhile, banks offer both classical banking products and investment accounts. That is why, if a bank is declared insolvent, its clients will have to use two different deposit insurance systems, what is more -systems operating according to different rules. Therefore, from the systemic perspective, and from the point of view of the clients of financial institutions, the concept of organizational merger of the deposit insurance system with a system guaranteeing loss compensation to investors should be finally implemented.

In response to the contemporary global financial crisis, European policy makers, including the European Commission decided to strengthen the sense of security of the European depositors. Therefore, they decided to raise and unify the guaranteed amount and to shorten the time of pay-out of guaranteed deposits (from 3 months to 20 days, and then, eventually to 7 days). The guaranteed deposit amount was raised to 100 thousand Euro and unified within the entire European Union, in the name of social justice and equal opportunities for EU citizens. Nevertheless, we should remember that different European countries have different purchasing power. Moreover, in the case of nonEurozone countries, there is a foreign exchange risk which may affect the final amount paid out in the national currency.

Beneficiaries of the above changes were the clients of financial institutions, which were declared insolvent, while the cost of this operation is borne mostly by the banks. However, banks are not charity institutions and therefore they may try to transfer the higher cost of maintaining deposit guarantee schemes onto their clients. Thus, the clients more and more share the cost of maintaining the system of pay-outs to those customers whose deposits are no longer available.

\section{Change in the role of the European Central Bank}

It is evident that the role of central banks has changed. Formerly „quiet” institutions, ,on the sidelines" of economic policy, they have become the frontline players, „supergovernments”, „the last resort” in boosting economic growth. Central banks 
(excluding the National Bank of Poland) started to provide aid directly to the governments and financial institutions, ,pump” enormous funds into economy, which had never been done before.

Since the standard monetary policy instruments were not sufficient to tackle the crisis effectively, some central banks started to take action which was earlier considered illicit or inadmissible. Direct aid to governments or financial institutions is one of such examples.

Non-standard instruments were also included in the instrumentarium of the European Central Bank. The most important non-standard instruments applied by the European Central Bank include:

- unconditional buy-out of covered bonds, which has been carried out periodically since July 2009 ,

- unconditional buy-out of treasury bonds: from Greece, Portugal and Ireland (2010-2012) and from Spain and Italy (2011-2012),

- $\quad$ unconditional buy-out of asset-backed bonds since November 2014.

One of the most prominent non-standard instruments is quantitative easing, which consists in increasing money supply (money stock) through purchase of financial assets from banks by the central bank in order to encourage them to promote credit growth. The European Central Bank introduced quantitative easing - buying out government bonds and private assets (later including bonds issued by regional authorities) - relatively late, i.e. only in March 2015, purchasing 60 billion Euro monthly (this amount is limited to 30 billion monthly from January 2018 on). This fact could be associated with the change of the Governor of the European Central Bank, or considered to be a pure coincidence.

The question about long-term effects of quantitative easing - also dubbed „helicopter money" - remains open. What will the return to standard central bank operation be like, and - more generally - what should this „,normality” look like. Additionally, there is an important question about what central banks will do with "toxic" assets, which they keep in their portfolio.

An important and positive step was to create macroprudential supervision, which focuses on identification and analysis of systemic risk, and on preventing destabilization of financial markets and economy. Its role is therefore to prevent macroeconomic imbalances. Risks which are important for macroprudential supervision include, for example, deepening debt crisis or overheated economy and appearance of speculative bubbles. The borderline between the activity of macroprudential supervision and economic policy is therefore blurred. Thus, cooperation between the bodies of macroprudential supervision and the governments is essential.

Microprudential supervision concentrates on assessing individual financial market institutions and tries to ensure safety of their operation and their clients. It prepares e.g. binding technical standards, issues interpretation guidelines, clarifies discrepancies in the opinions between national supervision institutions and is competent to resolve disputes (binding mediation).

The European macroprudential supervision was entrusted with the European Systemic Risk Board (ESRB), while the banking microprudential supervision - with the European Banking Authority (EBA). The European Systemic Risk Board is a „new” independent EU body at the European Central Bank, and the ECB governor is its chairman. The European Banking Authority is also a „new” independent EU body, 
which is supposed to cooperate - among others - with the European Systemic Risk Board.

Table. 1. Bodies of European microprudential supervision

\begin{tabular}{|l|}
\hline European supervisory authorities \\
\hline European Banking Authority in London \\
\hline The European Securities and Markets Authority in Paris \\
\hline European Insurance and Occupational Pensions Authority in Frankfurt am Main \\
\hline national supervisory bodies \\
\hline
\end{tabular}

Source: own study

As it was mentioned above, operating within the European banking union, the European Central Bank took over direct supervision of the largest Eurozone banks, i.e. 119 banks (holding approx. $82 \%$ of Eurozone bank assets):

- where the total value of the assets exceeds 30 billion Euro, or

- where the total value of the assets exceeds 5 billion Euro and the bank runs important cross-border activity (the ratio of its cross-border assets/liabilities in more than one other participating Member State to its total assets/liabilities is above $20 \%$ ), or

- which were considered to be important banks by the European Central Bank upon request of the national supervisory body, or

- $\quad$ have received funding from the European Financial Stability Facility (EFSF) or from the European Stability Mechanism (ESM), and also

- which are the three most important banks in each of the participating Member States.

The above means that the supervisory competences are transferred from the national to the European level. Transferring supervision to the European Central Bank was motivated by - at least theoretical - autonomy of this institution. Nevertheless, supervisory decisions were entrusted with the ECB Governing Council, where only the governors of Eurozone central banks are represented. Hypothetically, if Poland entered into close cooperation within the European banking union, it would not have its representative in the ECB Governing Council anyway and thus would not have any influence on its final decisions.

Moreover, transferring supervisory competences onto the level of the European Central Bank, without thorough change of the present supervisory structure made the institution "grow by multiplication" while the competences and responsibilities became less clearly defined. In extreme cases, a Eurozone bank may fall into the jurisdiction of five supervisory bodies, i.e. ECB, ESRB, EBA, supervisory body in the home state and in the host state.

The problems outlined above result among others from a lack of realistic possibility to change the Treaty on the functioning of the European Union. Some of the present policy makers cannot be eliminated and replaced with new actors nor can new actors be introduced. Therefore the present policy makers approve the decisions of the new actors. Thus, the lack of realistic possibility to change the Treaty on the functioning of the European Union should be considered as one of the very important UE political risks, 
which is yet another manifestation of the contemporary crisis and is reflected in the institutional and economic conditions.

\section{SIFIs - an unsolved problem}

One of the criteria of classification of the banks is their size. Banking literature and practice has long known the concept of banks which are „too big to fail”. Recently, this concept has been extended to include a notion of Systemically Important Financial Institutions (SIFIs) ${ }^{1}$. Both these terms refer to the largest banks, whose financial problems may pose a threat to financial stability or even to the public finances. For example, the largest bank registered in the European Union, i.e. HSBC in mid-2017 managed the assets worth nearly 2.5 billion USD.

If such big banks fall into financial difficulty, they are usually saved by means of public funds. Such banks (collecting deposits) are not declared insolvent since the deposit insurance schemes are not able to pay out the guaranteed amounts, considering the assets at their disposal. It is therefore required that deposit insurance schemes have now only at least $0.8 \%$ of guaranteed deposits. This gives rise to the phenomenon of the so called moral hazard: the largest banks know that if they fall into financial difficulty, they will be saved anyway.

In response to the contemporary global financial crisis, an attempt was made to solve the problem of SIFIs, which unfortunately failed due to the fact that EU policy makers gave in to the pressure of the banking lobby.

An 11-member Expert Group chaired by E. Liikanen was created to propose structural reforms of the European banking sector aimed at solving the SIFIs problem. Among the five recommendations offered in the so called Liikanen Report, there was one which shows the need to separate legally the deposit-credit banking sector from investment banking operations. Separating these two areas would apply to the entities whose investment activity exceeded $15-25 \%$ of their assets or 100 billion Euro. This would entail a change of the structure of the European banking sector, and that is why it encountered strong opposition of the banking lobbyists and eventually left the SIFIs problem unsolved. Perhaps ,small is beautiful” but big is definitely more powerful.

\section{Proposals of further reforms}

In December 2017 other proposals of further Eurozone reforms, which favoured even stronger integration, were announced. One of the most important proposals envisages creation of the European Monetary Fund (EMF) and appointment of the European Minister of Finance and Economy.

At present, however, it is not possible to fully assess the proposal which envisages creation of the European Monetary Fund which is supposed to be based on the European Stability Mechanism (ESM). Its financial and institutional framework would, in principle, remain the same as in the ESM. It would continue providing aid only to the Eurozone Member States which are in a difficult financial position and also it would provide support to the Single Resolution Fund (a kind of last resort lender in the

\footnotetext{
${ }^{1}$ More on this topic in: M. Zaleska, „SIFIs - nierozwiązywalny problem?” w „Eseje o stabilności finansowej”, A. Alińska (red.), CeDeWu, Warszawa 2012, str. 385-388.
} 
resolution process). The only difference would be the possibility to help banks in all banking union countries, not only those in the Eurozone. Theoretically, it should help some EU countries to seek independence from the IMF funds. The EMF should also operate more quickly than the ESM, and it would be chaired by the European Minister of Finance and Economy. The minister would be the Vice President of the European Commission and the Eurogroup head at the same time (,three in one”), which could result in an attempt to impose the Eurozone members' opinion on the other Member States. The quality of cooperation between the new Minister and the ECB Governor will also matter.

The option for the non-Eurozone Member States which belong to the banking union to benefit from the aid of the European Monetary Fund encourages us to seek close cooperation within the European banking union. On the other hand, the fact that the final decisions are taken by the ECB Governing Council (with no Polish representative) anyway signals the need for caution.

Therefore, the proposed reforms are not comprehensive, which is also due to the fact that it is impossible to amend the Treaty (TFEU). Moreover, it will be difficult to achieve the goals set without collecting considerable sources of financing for effective operation of the European Monetary Fund, which has not even been mentioned.

That is why the proposed changes appear not quite precise, or even seem only to serve the EU propaganda purposes. There is one statement made by JeanClaude Juncker that we can support: „We started repairing our roof. But we have to finish this job (...) as long as the sun is shining." And perhaps we should add continuing Juncker's thought - that the above proposals for changes will not repair all the holes in the roof.

\section{Other challenges which remain unsolved}

Along with the political risk and the other challenges outlined above, the following should be considered as the most important issues contemporary Europe needs to address:

- insufficient long-term savings,

- underestimated risk of government securities.

Firstly, there is a need to increase long-term savings, especially in Poland. In this respect, we tag along behind other EU countries, both when we compare their value to GDP and when we compare the percentage of personal income put aside as savings. Savings are indispensable to finance economic development of a country, ensure its financial stability and increase the degree of its independence from foreign capital, which may go as quickly as it comes. From the citizen's point of view, savings give a sense of security and are a source of pensioner's income. Bearing in mind higher pensioner's income, which reduces the risk of social dissatisfaction in the future, and the development of capital market, policy makers should introduce additional tax reliefs for long-term savers as well as statutory solutions referring to REITs (Real Estate Investment Trusts) in Poland.

REITs could become real estate investment trusts listed at the Warsaw Stock Exchange, generating profit to the Polish individual investors which would be paid out in the form of an $80 \%$ dividend and supply the state budget with tax. It is in the interest 
of all generations of the Poles - in view of the recent reduction of the retirement age to create a safe and long-term instrument financing growth of our future pensions. The more so that most of the countries of the so called Old European Union introduced REITs already more than ten years ago; e.g. France in 2003, while Germany, Italy and Great Britain - in 2007. Potential argument claiming that real estate markets in these countries were fully mature while the Polish market was not yet ready for such a contemporary instrument, is not convincing. From among the new EU countries, Lithuania and Hungary introduced REITs successfully in 2008 and 2011, respectively. It only heightens the feeling that we have been left far behind.

Secondly, there is no idea how to defuse the ,ticking bomb" of the government securities on the balance sheets of European banks. These securities, which in European legislation are considered to be risk-free, in practice are not void of risk (to give only an example of the Greek government securities). Banks are not limited to buy securities and they do purchase them, while the governments are happy that there are investors who finance the state budget. The problem lies in the fact that the risk carried by these securities is not properly measured and secured and may lead to another outburst of the financial crisis. Policy makers unfortunately do not show much responsibility or we can even speak of their hypocrisy.

\section{Conclusions}

In the name of improving security of financial institutions and protecting their clients, the number and level of complexity of regulations referred to financial markets, and mainly to the banking sector was increased. Other segments of the financial market unfortunately have not been thoroughly reformed (e.g. the system of loss compensations to investors mentioned above).

The changes which were implemented certainly strengthened the banking system stability but nonetheless they will not protect us against another crisis. This is due not only to the shortcomings of the changes but also to new threats which have appeared and are also due to greater popularity of new technologies applied on the financial markets.

At the same time, the changes introduced by the policy makers increased the cost of maintaining financial security systems, including market supervision. This was naturally reflected in the higher operational costs of financial institutions, especially banks. Indirectly, it also affects the general public since banks try to transfer this additional financial burden onto their clients.

Moreover, in modern times we have seen a leadership crisis in Europe. Germany and France - despite their aspiration - did not live up to the standard. Great majority of the changes which are presented and assessed in this article were political in character and were introduced in response to different crisis situations (,putting out fires"), without a broader vision and strategy to improve the security system and infrastructure of the financial markets. More and more often, political factors dominated over the economic ones.

In result, the number of policy makers (actors) has increased (the so called „growth by multiplication"). New bodies were established without a thorough reform of the institutions which were already operating. This blurred the borderlines between competences and responsibilities, and prolonged the decision-making process. 
Another important aspect is the fact that the policy makers and the general public relatively quickly forget about the sources and effects of the crisis, and moreover they do not want to see some of the problems (e.g. risk related to the government securities). They do so because it is convenient in terms of their short-term priorities. However, there will be other policy makers in the future, not ,us" to face the problem. Still, decisions are made in short-term perspective, with no long-term vision or even strategy. And unfortunately, there is tacit permission for selected groups of policy makers not to observe some rules. The problem lies not only in the lack of necessary or appropriate regulations but also in the tacit permission not to play by them.

\section{Bibliography}

„Antykryzysowe działania wybranych banków centralnych w latach 2007-2010”, Narodowy Bank Polski, Warszawa, maj 2010

Czekaj J., Owsiak S., „O potrzebie rewizji paradygmatu o autonomii polityki monetarnej i polityki fiskalnej”, w: „W kierunku nowego ładu świata finansów”, red. J. Nowakowski, Oficyna Wydawnicza SGH, Warszawa 2015

"Global systemically important banks: updated assessment methodology and the higher loss absorbency requirement”, Basel Committee on Banking Supervision, Basel, July 2013

Gospodarowicz M., „System gwarantowania depozytów z uwzględnieniem indywidualnego ryzyka banku i ryzyka systemowego", Oficyna Wydawnicza SGH, Warszawa 2015

Hryckiewicz-Gontarczyk A., „Anatomia kryzysów bankowych”, Wydawnictwo Poltext, Warszawa 2014

„Informacja o działalności Komitetu Stabilności Finansowej w zakresie nadzoru makroostrożnościowego w 2016 roku”, Komitet Stabilności Finansowej, Warszawa, czerwiec 2016

Koleśnik J., „Bezpieczeństwo systemu bankowego. Teoria i praktyka”, Difin, Warszawa 2011

Koleśnik J., „Adekwatność kapitałowa banków”, Difin, Warszawa 2014

Koleśnik J., „Kształt nadzoru bankowego i regulacji nadzorczych w Unii Europejskiej i w Polsce”, w: „Instrumenty i regulacje bankowe w czasie kryzysu”, red. J. Nowakowski, Difin, Warszawa 2010

Kozińska M., „Przymusowa restrukturyzacja banków w Unii Europejskiej”, CeDeWu, Warszawa 2018

„Macroprudential Policy Tools and Frameworks, Progress Report to G20”, Financial Stability Board, International Monetary Fund, Bank for International Settlements, 27 October 2011

Miklaszewska E., "Zmiany strategiczne na europejskim rynku bankowym w okresie pokryzysowym”, Poltext, Warszawa 2018

Mikołajczyk M., „Instrumenty polityki makroostrożnościowej”, w: „Nauki ekonomiczne w XXI wieku”, red. R. Bartkowiak, P. Wachowiak, Oficyna Wydawnicza SGH, Warszawa 2014

„Nadzór makroostrożnościowy w Polsce - ramy instytucjonalno-funkcjonalne”, Komitet Stabilności Finansowej, Warszawa 2016

„Polska wobec światowego kryzysu gospodarczego”, Narodowy Bank Polski, Warszawa, wrzesień 2009

Zaleska M., „Bankowość”, Wydawnictwo C.H. Beck, Warszawa 2013

Zaleska M., „Europejska unia bankowa”, Difin, Warszawa 2015

Zaleska M., „Gwarancje depozytów bankowych w świetle kryzysu” w: „Nauki społeczne wobec kryzysu ekonomicznego", red. J. Osiński, Oficyna Wydawnicza SGH, Warszawa 2009

Zaleska M., „Gwarantowanie depozytów”, w: „Bankowość detaliczna”, red. J. Koleśnik, Difin, Warszawa 2016 
Zaleska M., „SIFIs - nierozwiązywalny problem?”, w: „Eseje o stabilności finansowej”, red. A. Alińska, CeDeWu, Warszawa 2012

Zaleska M., „Świat bankowości”, Difin, Warszawa 2018

Zaleska M., „The System of Deposit Guarantees and of the Security of the Banking System in Poland in the Context of Global Systemic Challenges” in „The Banking System in Poland”, edited by H. Żukowska, M. Żukowski, Maria Curie-Skłodowska University Press, Lublin 2008

Zaleska M., „Współczesna bankowość”, Difin, Warszawa 2007

Zaleska M., „Zmiany zasad gwarantowania depozytów w odpowiedzi na globalny kryzys finansowy” w: „Instrumenty i regulacje bankowe w czasie kryzysu”, red. J. Nowakowski, Difin, Warszawa 2010

\section{Articles}

Hart O., Zingales L., A New Capital Regulation For Large Financial Institutions, "CEPR Discussion Papers" No. 7298/2009

Zaleska M., „Kompetencyjne zapętlenie”, Dziennik Gazeta Prawna z 10-11 listopada 2015

Zaleska M., "Kryzys przywództwa", Gazeta Bankowa nr 7/2017

Zaleska M., "Z dużej chmury średni deszcz", Gazeta Bankowa nr 1/2018

Zaleska M., "Źródła kolejnego kryzysu finansowego”, Rzeczpospolita z 3 stycznia 2018

\section{Legislation}

Regulation (EU) No. 575/2013 of the European Parliament and of the Council of 26 June 2013 on prudential requirements for credit institutions and investment firms and amending Regulation (EU) No 648/2012 (Official Journal No L 176 of 27 VI 2013)

Directive 2013/36/EU of the European Parliament and of the Council of 26 June 2013 on access to the activity of credit institutions and the prudential supervision of credit institutions and investment firms, amending Directive 2002/87/EC and repealing Directives 2006/48/EC and 2006/49/EC (Official Journal No L 176 of 27 VI 2013)

Directive 2014/49/UE of the European Parliament and of the Council of 16 April 2014 on deposit guarantee schemes (Official Journal No L 173/149)

Act of 5 August 2015 on macroprudential supervision over the financial system and crisis management in the financial system (Polish Journal of Laws of 2015, item 1513 as amended)

\section{Streszczenie}

W opracowaniu przedstawiono głównych europejskich decydentów reform sektora bankowego w odpowiedzi na współczesny, globalny kryzys finansowy. Dokonano również oceny wprowadzonych zmian instytucjonalnych, w tym stworzenia europejskiej unii bankowej, modyfikacji w unijnych systemach gwarantowania depozytów oraz istotnego zwiększenia roli banków centralnych, ze szczególnym uwzględnieniem Europejskiego Banku Centralnego. Ponadto zidentyfikowano potencjalne źródła kolejnego kryzysu finansowego oraz zaprezentowano propozycję dalszych zmian instytucjonalnych w sferze finansów.

Słowa kluczowe: kryzys finansowy, reformy bankowe, sieć bezpieczeństwa finansowego, bank centralny

Informacje o autorze:

Prof. Malgorzata Zaleska, Phd

The Institute of Banking, Warsaw School of Economics

Al. Niepodległości 162, 02-554 Warszawa

e-mail: malgorzata.zaleska@sgh.waw.pl

ORCID: 0000-0003-3963-7298 